\title{
Water Circular Economy at the Kwinana Industrial Area, Western Australia-the Dimensions and Value of Industrial Symbiosis
}

\author{
C. Oughton ${ }^{1,2}$ (D) M. Anda ${ }^{2} \cdot$ B. Kurup ${ }^{2} \cdot$ G. $\mathrm{Ho}^{2}$
}

Received: 27 January 2021 / Accepted: 9 June 2021 / Published online: 27 July 2021

(C) The Author(s), under exclusive licence to Springer Nature Switzerland AG 2021

\begin{abstract}
The major industrial companies located in the Kwinana Industrial Area (KIA) produce many industrial, agricultural and mining chemicals and refined materials, for national and international markets. With over 150 documented product and by-product exchanges, Kwinana is considered to be one of the best examples of industrial symbiosis (IS) in the world. A new model of IS comprised of four dimensions is under development, whereby whilst each dimension is unique, collectively, they interact to characterise an industrial estate, thus contributing to the evolutionary understanding of IS. We investigate the basis for this model through an analysis of two water circular economy examples as they relate to Western Australia's premier industrial area, the KIA. Case studies will consider a managed aquifer recharge (MAR) project that failed and the process water interconnectedness of enterprises operating successfully as a sub-ecology within the industrial cluster. Apart from the traditional product and by-product dimension of IS, three additional dimensions seem to be playing a crucial role in the KIA, these being the skilled workforce, support industry and governance dimensions. We provide additional context for the water-related examples of the circular economy at Kwinana by exploring a new four-dimensional model for IS.
\end{abstract}

Keywords Industrial symbiosis · Water circular economy $\cdot \mathrm{KIC} 4 \cdot$ Kwinana Industrial Area · Dimensions of symbiosis

\section{Abbreviations \\ AMC Australian Marine Complex \\ CE Circular economy \\ EE Eco-efficiency}

C. Oughton

Chris.oughton@kic.org.au

1 Kwinana Industries Council Inc, 11 Stidworthy CourtWA 6966 Kwinana, Australia

2 Engineering \& Energy, Murdoch University, Perth, Australia 


$\begin{array}{ll}\text { IS } & \text { Industrial symbiosis } \\ \text { IE } & \text { Industrial ecology } \\ \text { KIA } & \text { Kwinana Industrial Area } \\ \text { KIC } & \text { Kwinana Industries Council } \\ \text { KIC4 } & \text { Kwinana Industries Council four dimensions (as devised by the author) } \\ \text { KISP } & \text { Kwinana Industries Synergies Project report to KIC, 2020 } \\ \text { KWRP } & \text { Kwinana Water Reclamation Plant } \\ \text { MAR } & \text { Managed aquifer recharge } \\ \text { PSDP } & \text { Perth Seawater Desalination Plant } \\ \text { RIZ } & \text { Rockingham Industry Zone } \\ \text { SDOOL } & \text { Sepia Depression Ocean Outlet Landline } \\ \text { SDGs } & \text { Sustainable Development Goals } \\ \text { WC } & \text { Water Corporation } \\ \text { WTC } & \text { Western Trade Coast } \\ \text { WWTP } & \text { Wastewater treatment plant }\end{array}$

\section{Introduction}

\section{IS to CE}

It was in the late 1980s when writers were publishing papers on what was then referred to as industrial ecology arising along with the sustainability thinking in relation to industrial areas [1-4] describing this as "industrial metabolism" and a system for the transformation of "wastes" into raw materials [4]. At the 1992 Earth Summit, the World Business Council for Sustainable Development presented its publication entitled "Changing Course", thus endorsing "eco-efficiency" [5] as a new way for business to implement Agenda 21. During the first years of the 2000 millennium, "eco-efficiency" was a term commonly used to describe industry's quest to drive internal production costs lower. The acceptability of industry as a system that evolves, much like the natural ecological system does, was gaining momentum. Wallner [6, 7] went on to propose, from his two articles, that industry's movement from unsustainable production to sustainable production was an evolutionary process. Supporting this thinking, only a year later, the natural environment, or ecology, was used as a metaphor for industrial ecology [8]. Since those times, much research documenting this evolution has been published, more especially in recent years. In a paper by Neves et al. [9], a comprehensive review of IS was undertaken where some 584 publications on the subject were reviewed. The aim of Neves' work was to "trace the trend of IS research and to map the existing case studies around the world, with a critical analysis of its impact". Their findings expose a dominance (70\%) of the research articles on IS being written from 2007 onwards, and continuing to increase, their publication being predominant in two journals (Cleaner Production and Industrial Ecology), the main type of content being "theoretical" (48\%), the economic activity category (manufacturing) representing $62 \%$ of published case studies, rising to $78 \%$ with the addition of the water/wastewater management activities.

\section{Motivation for Research}

The pursuit of IS worldwide is well documented [see Section 2] and has been an influencing driver towards "circular economy" industrial areas, primarily for the purpose of reducing 
waste. The world's most advanced countries and organisations have been signalling an expected transition to $\mathrm{CE}$ principles for some time, and expectational targets are there to be seen. Despite progress in this area, the success of industrial clusters is wildly variable.

In the context of the State of Western Australia, for example, the KIA, a strategic industrial area in the state is a significantly more successful example of a complex industrial cluster than similarly designated industrial clusters located only 120 kilometres to the south (Kemerton) and 500 kilometres north (Oakajee). The process of identifying why the differences in the success of these industrial areas will be carried out in the future using the framework of a new model for IS, which we are proposing and which is referred to as the KIC4 dimensional model for IS. This new model is described in Section 3.

The specific objectives of this paper are as follows:

1. Provide an overview of the literature on the evolution of IS.

2. Describe the proposed four dimensions of the KIC4 model of IS.

3. Present findings from the two water circular economy case studies in KIA.

4. Apply the KIC4 model as they relate to the Kwinana water circular economy.

5. Derive conclusion on the appropriateness of the KIC4 model to water circular economy.

\section{Literature Review}

\section{Industrial Symbiosis-40 Years of Evolution}

IS evolved from the domain of industrial ecology (IE) and the sustainability movement $[1,2]$ where a "natural (environmental) ecology" was used as a metaphor for industry's material exchanges [8]. Chertow [1,2] cited the model of IS as being notably expressed in the ecoindustrial park at Kalundborg, Denmark. In her publication, she presents an exchange model involving ten companies and 14 material exchanges. Prior to this, in the late 1980s, writers were publishing about industrial ecology. In 1989, Frosch and Gallopoulos [10] described IE where "the consumption of energy and materials is optimized and the effluents of one process ... serve as the raw material for another process". At the same time, Ayres [4] described places where IE was evident as "systems for the transformation of materials" and "industrial metabolism". At the 1992 Earth Summit, the World Business Council for Sustainable Development presented its publication entitled "Changing Course", thus endorsing "eco-efficiency" [5] as a new way for private sector business to implement Agenda 21. In 1996, Wallner and Narodoslawsky [6,7] were part of the momentum behind the sustainability movement, proposing that industry progressing from unsustainable to sustainable production was an evolutionary process taking industry towards "islands of sustainability". Since those times, much research documenting this evolution has been published, more especially in recent years. In a paper by Neves et al. [9], a comprehensive review of IS was undertaken where some 584 publications on the subject were reviewed. The aim of the work was to "trace the trend of IS research and to map the existing case studies around the world, with a critical analysis of its impact". Their findings expose a dominance $(70 \%)$ of the research articles on IS being written from 2007 onwards, and continuing to increase, their publication being predominant in two journals (Cleaner Production and Industrial Ecology), the main type of content being "theoretical" (48\%), the economic activity category (manufacturing) representing $62 \%$ of published case studies, rising to $78 \%$ with the addition of the water/wastewater management activities. 
Several formal studies over time have mapped the development of the symbiotic exchanges between the companies located within the KIA [3, 11-17]. These studies almost all focused their attention on the project, process and platform levels that are required to be present in order to develop and establish symbiotic (material) exchanges between industries. Fig. 1 illustrates diagrammatically the relationship between project, process and platform within the context of material and utility exchanges within an industrial cluster.

Literature, and indeed its practical application, indicates that the internationally accepted understanding of IS is that it contemplates the exchange of products, by-products and utilities (usually) within a complex industrial cluster. This appreciation appears to focus on the associated aspects of the broader value (social, economic, environment etc) that IS creates $[17,18]$. Since 2000 , the academic community outside of Australia has tended to define IS on the basis of experiences primarily collected from Kalundborg and is described by Chertow as:

Industrial symbiosis engages traditionally separate industries in a collective approach to competitive advantage involving physical exchange of materials, energy, water, and/ or by-products. The keys to IS are collaboration and the synergistic possibilities offered by geographical proximity [1].

From this, one is able to draw out some important aspects of IS. Separate industries collectively pursuing competitive advantage through collaboration, for example. We also note the mention of the geographic location here. The definition limits itself to the exchange of

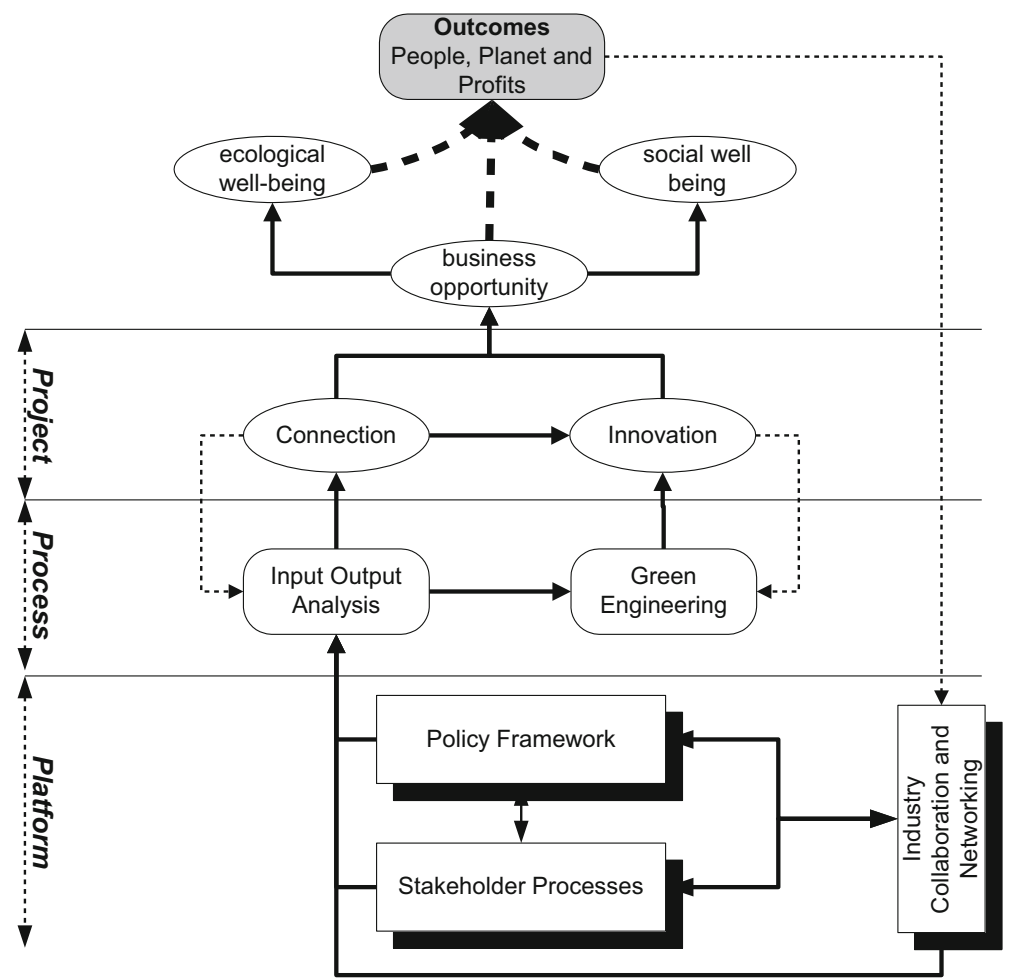

Fig. 1 Descriptive model for realisation of regional resource synergies (source: [11]) 
materials, etc. Chertow [1] further developed the definition by adopting the approach that as a minimum, there needs to be at least three independent entities engaged in the exchange of more than two materials to qualify to be regarded as IS. This was referred to by Chertow as the 3-2 heuristic model. What this does is extend a reference to IS beyond a mere linear relationship where a material is exchanged between two entities, to multiple exchanges within complex relationships. Jensen $[19,20]$ in two papers discussed the importance of geospatial industry diversity - a range of different enterprises in one larger geographic location - and the role of those diverse enterprises being located together in an industrial complex. These elements, geoproximity and geospatial diversity, are clearly applicable characteristics within the KIA. Because of the experiences they had from the National Industrial Symbiosis Programme (NISP) a decade later, practising consultants and the facilitators from the UK further extended the definition:

Industrial symbiosis engages diverse organisations in a network to foster ecoinnovation and long-term culture change. Creating and sharing knowledge through the network yields mutually profitable transactions for novel sourcing of required inputs, value-added destinations for non-product outputs, and improved business and technical processes [18].

Key elements in this definition tend to link Jensen's geospatial diversity to Chertow's materials re-use and cost competitiveness. Lombardi is beginning to bring in aspects of enterprise ecoinnovation and culture change. We see this emergence of thought as leading to other less definable aspects of IS, broadening the world view of IS perhaps into aspects not yet considered.

More recently, Luciano et al. [21] concluded that diverse (independent) organisations, in their sharing of knowledge through their networks, created benefits in addition to those gained through their product, by-product and utility synergies. In their case study of the East Sicily Industrial Park, it was concluded that the mere existence of the opportunity for IS alone did not deliver actual IS outcomes for new, appropriately aligned industries, even though these industries demonstrated an appropriate alignment of their business sustainability, the skill sets of their people and their interaction within the broader environment. Luciano makes reference to the diversity of enterprises as part of the creation of IS benefits in addition to the usual material exchanges. He concludes that something else beyond "the mere existence of opportunity" leads to improved competitiveness. Without saying it directly, he leads the reader to consider what else is therefore needed to improve "business sustainability". Lombardi's definition of IS refers to diverse organisations or an industrial cluster, where the presence of commercial stand-alone transactions is characteristic and where the exchange of inputs and outputs is agreed between a sender and receiver to improve business outcomes. Scholarly papers $[1,18,21]$ have defined the evolution of the traditional "product/by-product/ utility exchange" view of IS to a recently emerging consideration of other less definable, or esoteric, aspects of IS. Others have developed a range of models that look further than the mere exchange of materials. Kurup's [17] "Six Capitals" model explores the broader economic, social and environmental impacts of these IS exchanges, and they do continue the trend of broadening the contextual framework of the single dimensional view of IS. Undoubtedly, this work has contributed to the body of knowledge through a greater understanding of the benefits of a functional industrial ecology that finds its base limited to IS material exchanges. 
Another model by Artem, in a study into another of Australia's heavy industrial area, Gladstone, focused on the development of an IS "maturity grid" [22]. Artem's model was developed in the recognition that there can be a range of factors limiting the development of IS, including environmental regulation, poor trust and cooperation between industries, lack of information and economic barriers. Use of the model provides an insight into the degree to which the maturity of the IS collaborations has evolved. It broadens the contemporary thinking about IS into areas that are beyond the mere exchange of materials. This is a useful introduction to the KIC4 model's dimensional approach.

In 2009, Chinese law promoting CE materials flows came into force, promoting circular (not the characteristic linear movement via IS) flows. This has provided considerable momentum to the emergence of scholarly research investigating this new field of study [23]. They posit that whilst CE is gaining momentum in the promotion of closed materials cycles, product re-use and the promotion of production and supply chains to improve resource efficiency, it doesn't extend into the higher-level economic institutional (and social) dimensions. They illuminate the problem that $\mathrm{CE}$ does not venture into the labour and governance dimensions, and they ask who should bear these beyond the enterprise costs.

The United Nations [24] adopted Resolution 70/1 in 2015. Cechin et al. [25], in analysing the UN goals, identified 7 where IS can make a contribution, further identifying the specific relevant targets that can be applied under "IS". In their conclusions, they group industrial ecology, ecological modernisation and green economy within the higher-order circular economy framework, itself fitting within the sustainable development framework.

We turn now to identifying the strengthening connection between IS and with CE. Alvarez [26] observes that the European Union Data Centre on Waste is reporting reductions below policy targets and expectations. Efforts are being directed towards identifying new waste reuse policy (governance) targets and means by which these can be achieved. Continuing this theme, several obstacles to the development of IS projects in Europe were identified [27]. These included provision of weak economic incentives (IS exchanges are often low margin), geographic variations on incentives and drivers, varying policy frameworks (taxes and levies) and difficulty in navigating geographic boundaries (bureaucracy). Tseng et al. [28] points to a limited expression of circular economy, in that it remains somewhat focused upon resource regeneration, environmental sustainability and closed-loop supply chains. However, the less publicised yet more societally advantageous economic benefits of $\mathrm{CE}$ are through a multi-loop, multi-level assessment approach which extends beyond the traditional IS approach.

\section{The Western Trade Coast}

\section{The Kwinana Industrial Cluster}

This paper considers two examples of its water CE through the lens of a proposed fourdimensional model for IS. The model of IS presented in this paper is under development by the Kwinana Industries Council (KIC). The KIC advocates for the collegiate interests of its members and works to achieve progress across a series of key strategic issues (Kwinana Industries Council, Annual Report. 2020, Kwinana Industries Council: Perth, Australia, https://kic.org.au/wp-content/uploads/2020/11/KIC-Annual-Report_RS_-2020.pdf). It was incorporated as an Industry Association in 1991 by the industrial enterprises located within the KIA, and it is geographically focused entirely on the greater Western Trade Coast (WTC), 
from which it draws its membership. Whilst the number of members can vary from time to time, KIC includes in its membership 14 full member (major industrial) enterprises and around 20 associate members. The emerging model is referred to as KIC4; a four-dimensional model of IS. It is being presented as another evolutionary step in the practical application of IS. The proposed model is based on four dimensions of IS, these being the product and by-product synergy dimension, the skilled workforce, supporting industry and the governance synergy dimensions. The KIA is often referred to in scholarly research papers [14, 16, 17, 29] in reference to the maturity and extent of its product, by-product and utility synergies. The WTC is formally designated as one of Western Australia's strategic industrial areas (https:// developmentwa.com.au/sia) and is located $30 \mathrm{kms}$ south of the Perth Central Business District in Western Australia (Fig. 2).

The WTC is made up of four primary industrial suburbs (Fig. 3). The original heavy industrial core, otherwise known as the KIA, is highlighted in yellow. It was established in 1955 to create an industrial area far enough away from Perth to accommodate the first entrant, the BP Kwinana oil refinery. Today, the KIA is almost completely built out with heavy industry, and it is where the vast majority of the product, by-product and utility synergy exchanges occur. The WTC directly and indirectly employs some 30,000 workers, direct and indirect, who attribute their employment to the WTC, with $65 \%$ of them living within 15-20 kms of their place of employment. The economic contribution to the state of WA by the companies located within the WTC is approximately $\$ 16 \mathrm{Bn}$ pa [29]. The Australian Marine Complex (AMC) is depicted by the blue area. This area focuses on ship building and maintenance, defence industries and specialist resource fabrication and sub-sea engineering. Adjacent to this, to the north, is the Woodman Point Wastewater Treatment Plant (WWTP). The Rockingham Industry Zone (RIZ) is the area shaded in light green. It is a mixture of heavy and general industry zones and is the main location where the emerging Lithium Valley industries are located. It contains the East Rockingham WWTP. Latitude 32 is shown in blue. This area is largely undeveloped, but is likely to become the place where an expansion of the heavy and general industrial core will occur. The Kwinana WWTP is located nearby to the east. The WTC is contained within a world-class industrial buffer zone, the line of which is indicated by the dashed black line encircling the industrial suburbs.

The KIA has been well documented for its IS material exchanges and is widely regarded as one of the world's best practice examples of IS at work [3, 15, 30] exhibiting a strong inclination towards closing cycles across water, energy and materials [14, 17]. The synergy exchanges between the different companies were re-mapped in 2013 and reported in the 2014 SKM report [29], the fourth in a series of reports (Dames \& Moore, Kwinana heavy industry economic impact study. Prepared for the Confederation of Western Australian Industry. 1990, Prepared for the Confederation of Western Australian Industry, https://www. water.wa.gov.au/_data/assets/pdf_file/0004/8887/110703.PDF)). These reports represent many years of data compilation and reporting and present a chronological history of the development of IS in Kwinana. A further iteration of the exchanges was carried out in 2020 (see Fig. 4). Water-related infrastructure in this zone includes the Perth Seawater Desalination Plant (PSDP), providing in excess of $50 \%$ of Perth's potable water requirements, and the Kwinana Water Reclamation Plant (KWRP), which manufactures process water (5 GL per annum via reverse osmosis) for industry and recycles wastewater from a northern wastewater treatment plant. Consideration is being given to the construction of a second stage for the KWRP to meet increased process water demand from heavy industry. 


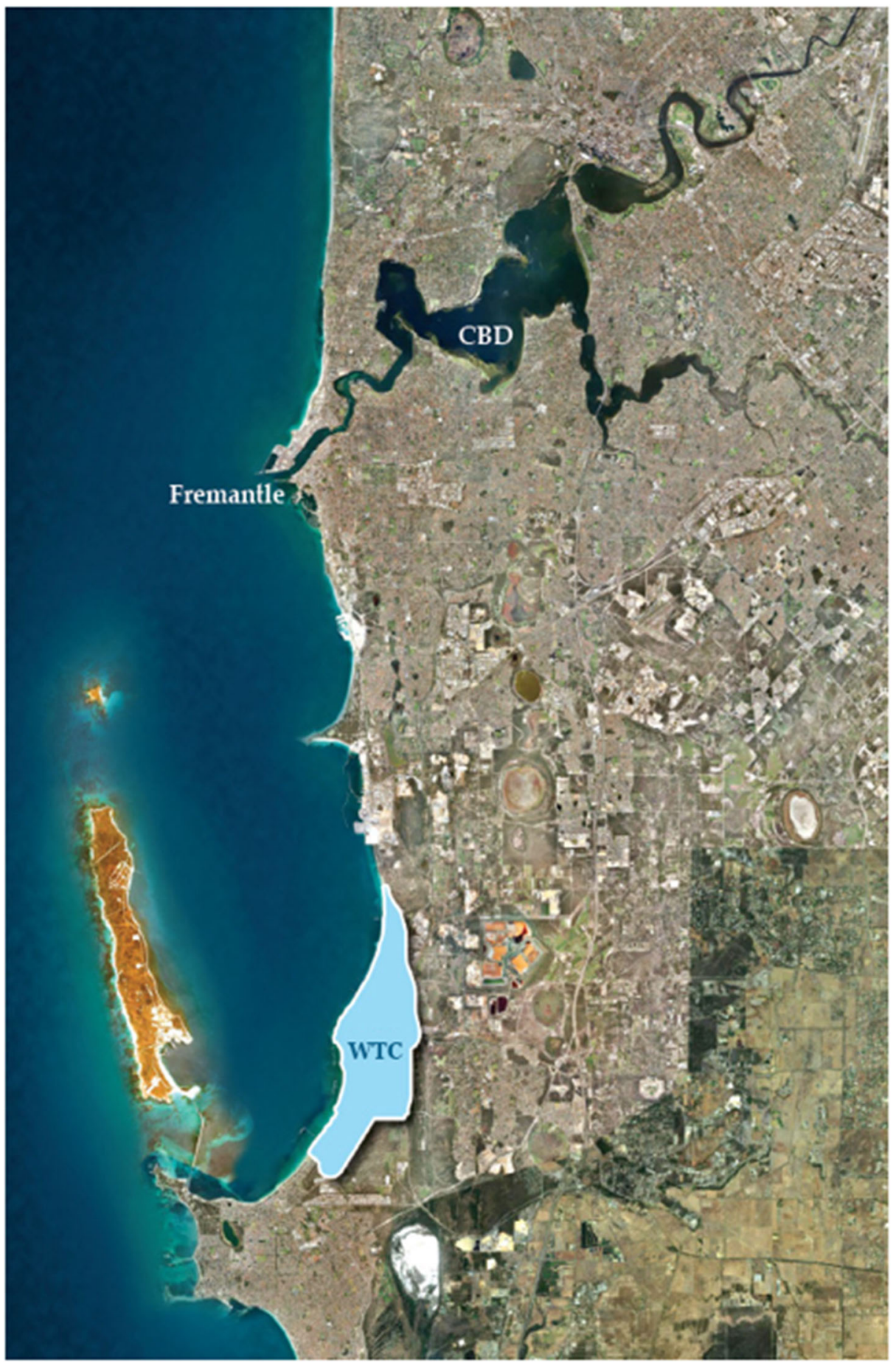

Fig. 2 Western Trade Coast within the Perth metropolitan area (KIC, 2020a) (https://kic.org.au/wp-content/ uploads/2020/12/KIC_Designated-Strategic-Industrial-Area_WTC-480x683.jpg) 


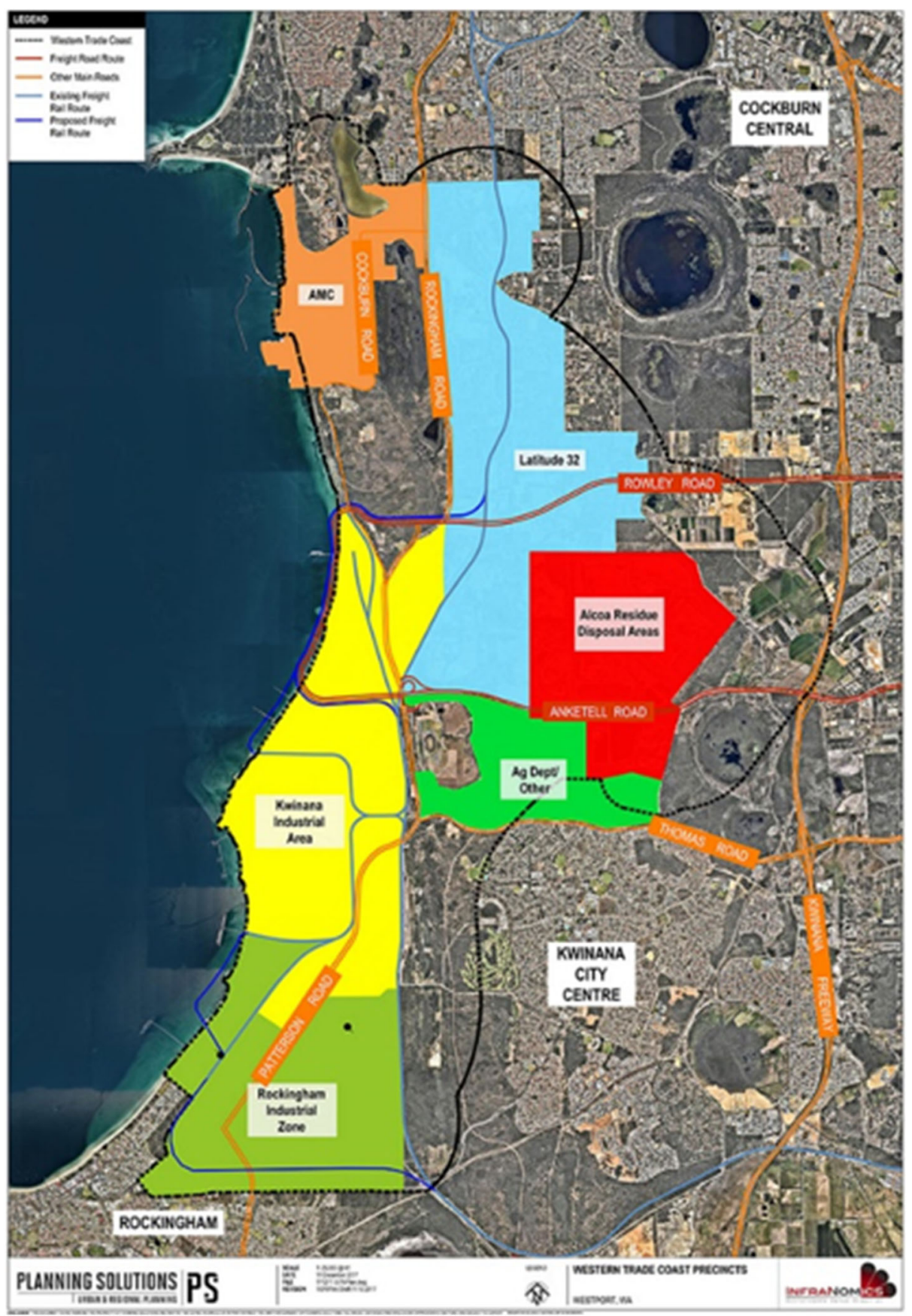

Fig. 3 Industrial precincts within the Western Trade Coast (KIC 2020b) (https://kic.org.au/wp-content/uploads/ 2019/11/KIC-Westport-Existing-Precincts-Map.jpg) 


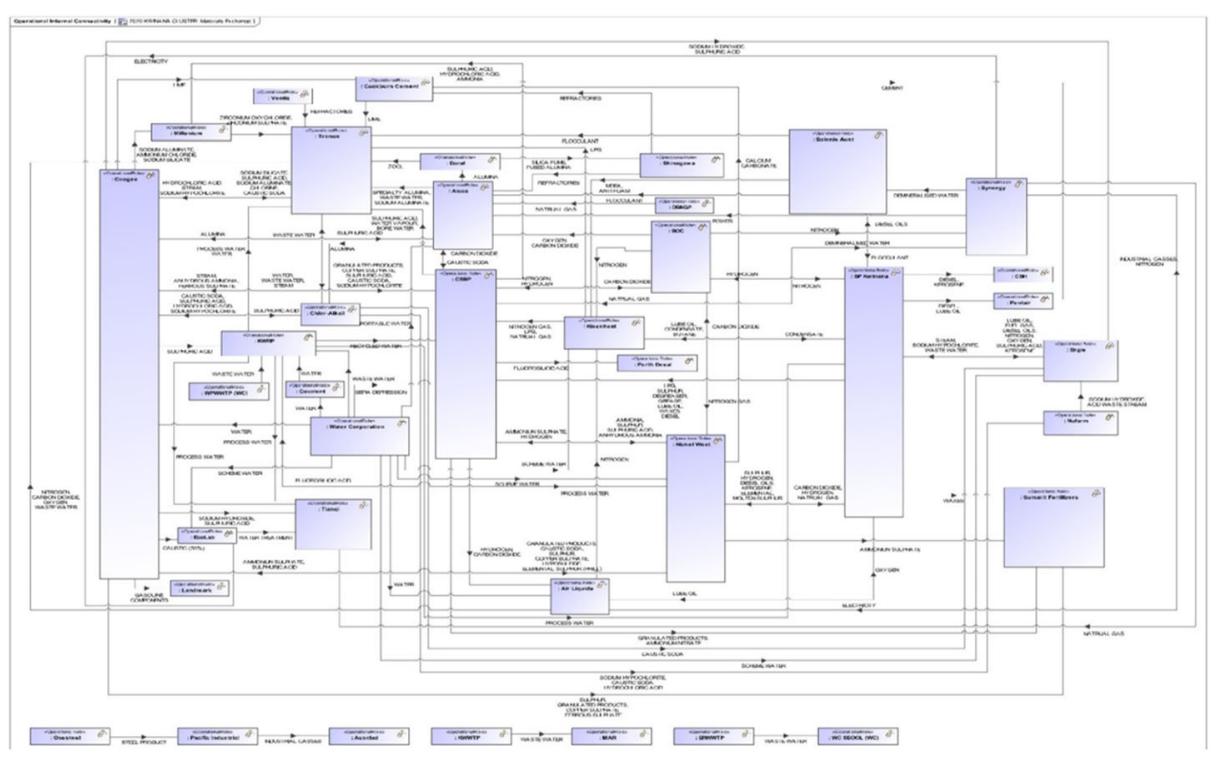

Fig. 4 Kwinana Industrial Area product/by-product/utility exchanges schematic KISP 2020

\section{Industrial Symbiosis, Water Circular Economy and Kwinana}

Significant process water re-use has been achieved over the years by industry itself. Water audits by industry from 2006 until 2016 saw total annual consumption reduce from 32.7GL to 28.5GL. This was due primarily to the economic return of reducing the acquisition of "new" water into the industrial processes. Barrington et al. [31] examined the water flows within the BP Kwinana oil refinery with a view to achieving the goal of water conservation towards the ideal of "zero liquid discharge". A water auditing technique was used within the management governance environment of "an overarching company policy to minimise water use and effluent discharge". Van Beers [14] referred to "beyond compliance" initiatives being adopted where competitive advantage could be achieved. Such initiatives were in many cases facilitated by the KIC through its formal committee structure which, in the years from 1995 to the late 2000s, included its Eco-efficiency Committee. This industry association-led formal governance approach saw numerous synergy initiatives devised and implemented. The Western Australian government [32], [33] from a policy perspective has established water recycling targets, and various government agencies have and continue to play a role in increasing the use and availability of water re-use [34].

For industry, the creation of policy targets is useful, but the practical application of these governmental roles (regulator and supplier) presents as difficult to navigate. The physical discharge under licence by the Water Corporation to the ocean of a substantial ongoing volume of secondary-treated wastewater (reported as 162.55ML/day in the 2019-20 Sepia Depression Ocean Outfall Landline Annual Summary Report [35]) represents for industry a major opportunity to resolve its process water availability issues, but access to the water is through the regulatory and physical supply channels and remains problematic. There is substantial interest from potential industry enterprises towards locating and establishing their operations within the WTC, and this new demand is not only consuming the available "plug and play" industrial land, it is also adding to an emerging industrial process water deficit (Fig. 5). 


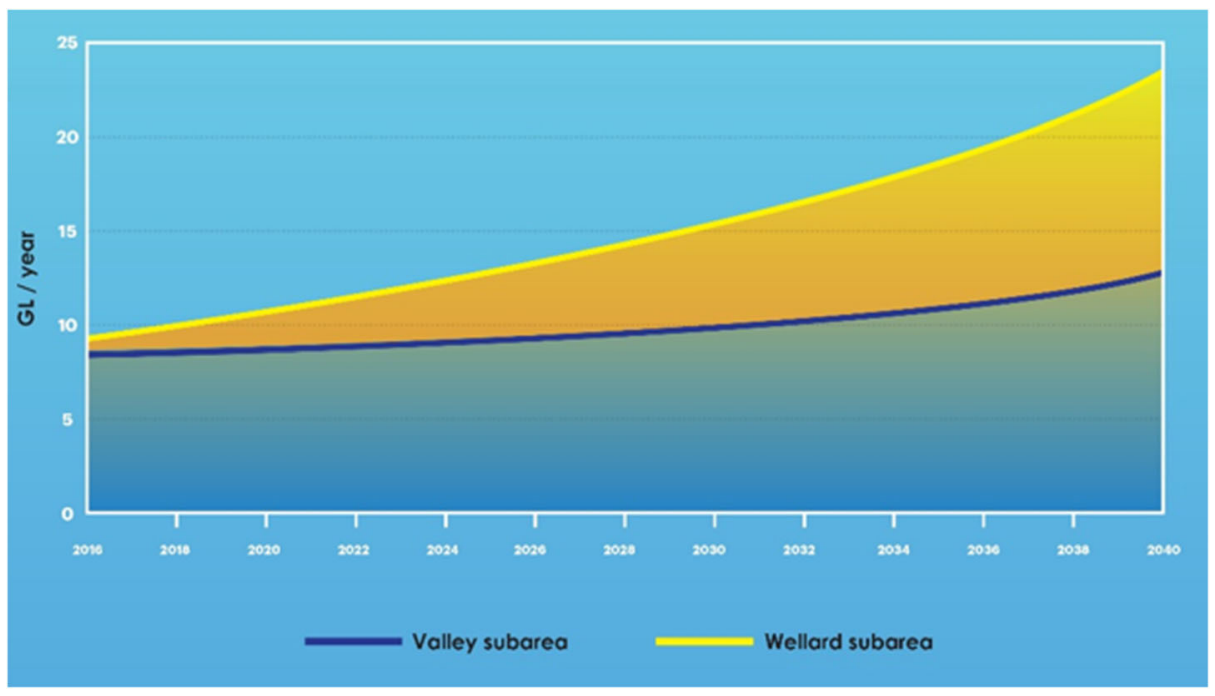

Fig. 5 Increased water demand projections for the Kwinana Industrial Area (Meechan, et al., 2019. Kwinana Industrial Area Water Management Strategy (unpublished report))

Groundwater, the extraction of which is licenced by the government regulator, has been the traditional source of industrial process water to the industries located in the KIA for decades. But in response to the drying climate, availability is slowly diminishing. The response of the Regulator is to cap (and potentially reduce) existing groundwater extraction allocations, and it has removed the option of an allocation to all new industry proponents. In WA, the production of potable water and the management of the returned wastewater is a government responsibility, which is delivered by the Water Corporation (WC), a government trading organisation. Operating within the WTC are several WC assets including three wastewater treatment plants, a seawater desalination plant and a plant (KWRP) (Kwinana Water Reclamation Plant - Water Technology (water-technology.net) that produces industrial process water from the wastewater outflow of one of the wastewater treatment plants. It is recognised that the solution to the increasing need for industrial process water within the reality of diminishing groundwater availability is managed aquifer recharge (MAR), whereby a proportion of the wastewater stream is brought up to a fit-for-purpose standard and then infiltrated into the very porous sand and limestone superficial aquifer (KISP (unpublished) 2020) [36].

KIC published its Issue Position Paper (KIC, 2014 position paper https://.perthnow.com.au/ news/peel-rockingham/water-shortage-looming-for-kwinana-industrial-area-warns-kic-ngb881084646z), entitled "The Managed Aquifer Recharge (MAR) Project for the Kwinana Industrial Area". It stated that "Supplementing the groundwater supply with a safe and affordable alternative supply is one of KIC's key strategic issues". Further, "Securing a long-term water source for the major industries within the KIA has been a priority for industry for several years". The issue (diminishing availability of the traditional source of industrial process water) is not new. A sustainable solution appears difficult to secure, and groundwater in the area (WTC) was fully allocated, with the consequence being an increasing reliance on expensive potable water supplies. Options for alternative water supplies, such as recycled wastewater to meet future demand by industry, were identified by the state government. Barrington et al. [31, 37] used water auditing within the CSBP fertiliser manufacturing facility to identify strategies leading to zero liquid 
discharge. It was identified that two major water conservation measures could reduce inputs and outputs by around $40 \%$ : collection and re-use of rainwater and engineering improvements to cooling towers. These studies demonstrated that further initiatives towards a water circular economy can be undertaken in the Kwinana Industrial Area.

\section{KIC4 Dimensional Model of IS}

As a framework for assessing the case studies, the KIC4 model is outlined here. In brief, the four dimensions are described by the model as firstly the Product and By-product synergy dimension, which reflects the traditional understanding of IS - the exchange of materials and utilities between industrial enterprises. With close to 200 exchanges operating on commercial terms, IS is very strong in Kwinana. An enterprise's competitive position is improved through participation in the material exchange of this first dimension.

Second is the skilled workforce dimension, where the collective industries interact with the cluster's workforce. This dimension refers to the "human resource synergy" in the WTC, to the almost 30,000 skilled and experienced workers that are directly and indirectly employed in KIA (Kwinana Industries Council, Annual Report. 2020, Kwinana Industries Council: Perth, Australia, https://kic.org.au/wp-content/uploads/2020/11/KIC-Annual-Report_RS_-2020.pdf). When a new industrial entrant builds its plant in Kwinana, it can actively target and attract workers from within the local area, thus entering its commissioning phase with a skilled and experienced employee base, complete with ready-made local knowledge. From the perspective of the industrial cluster, maintaining the human capital supports the long-term sustainability of the enterprises collectively. An enterprise's competitive position is improved when it can employ from a pool of skilled workers who in the main live nearby to their place of employment.

The third is the support industry dimension, where the heavy industry collective interacts with the support industries that exist primarily to service their requirements. Support enterprises locate near to the major heavy industries, to which they are commercially connected. These enterprises are the expert fabricators, constructors, engineering workshops, plant and labour hire suppliers, sand blasting and galvanising experts, maintainers of specialist equipment and deliverers of services such as waste management. Heavy industry has a strategic advantage in having the support industries located close by. An enterprise's competitive position is improved when it can rely upon ready access to the necessary range of support industry services that are required for business continuity.

Finally, the fourth dimension is proposed as the governance dimension, where the collective industries interact with the providers of policy and common user infrastructure. In this dimension, governance means policy leadership, environmental and safety regulation, strategic land use planning, facilitation and maintenance of common user support infrastructure, planning and environmental approvals and strategic business development. Much of this is delivered by the various levels of government, but it does also include the policy governance function operating within an enterprise. An enterprise's competitive position is improved when the (public sector) governance functions are delivered efficiently and effectively.

\section{Process Water Demand in Kwinana}

Kwinana industry relies heavily upon groundwater for its supply of industrial process water, with $56 \%$ of its overall demand met by this source (Meechan et al, 2019. Kwinana Industrial Area 
Water Management Strategy (unpublished report)) [38] (Fig. 6). The Western Australian Department of Water (DWER) has implemented capping of groundwater allocations to industry in Kwinana and has indicated that allocations may actually be reduced. No new allocations will be issued. This means further industrial development requiring process water will be directed towards other potentially more expensive options for their requirements. Reclaimed water refers to the supply of high-quality industrial process water reclaimed from secondary-treated wastewater (sewage) through secondary or tertiary treatment such as a reverse osmosis process. The cost of this water is reflective of the price of scheme water, and its availability, due to the cost of supply infrastructure, is limited to those industrial customers located reasonably close to the production facility. Scheme water refers to the use of the water that is produced for Perth's potable needs and is the only practical option available for new industry to use; it is also an expensive option. Industry has been very active for over a decade in reducing its water requirements, with new methods of re-use and recycling reducing its demand in 2006 from a total consumption of 37.2 GL down to 28.5GL in 2016 (Meechan et al, 2019. Kwinana Industrial Area Water Management Strategy (unpublished report)) [38]. Given the predominance of groundwater as the source of industrial process water, and its capped extraction rates, any combination of these factors creates, in essence, a cap on the options available for future industrial entrants. A new, additional, major source of process water needs to be identified and made available if industry is to avoid future capacity constraints related to process water supply.

There has been much research into the sources and uses of water for industry in Kwinana over the years (Kwinana Water Reclamation Plant - Water Technology (water-technology.net) $[11,12,39-48][3,17]$ [20]. Much of this work was commissioned and undertaken either directly or indirectly by government regulators or agencies. Research work will continue, and new efficiencies and sources of industrial process water will need to be found to ensure that the WTC can continue to accommodate new entrant enterprises without the need to resort to consuming expensive potable water supplies. The Kwinana Water Reclamation Plant (KWRP) facility produces around 5GL of reverse osmosis industrial process water from secondarytreated sewage annually, with the water recovered otherwise being piped to waste via the

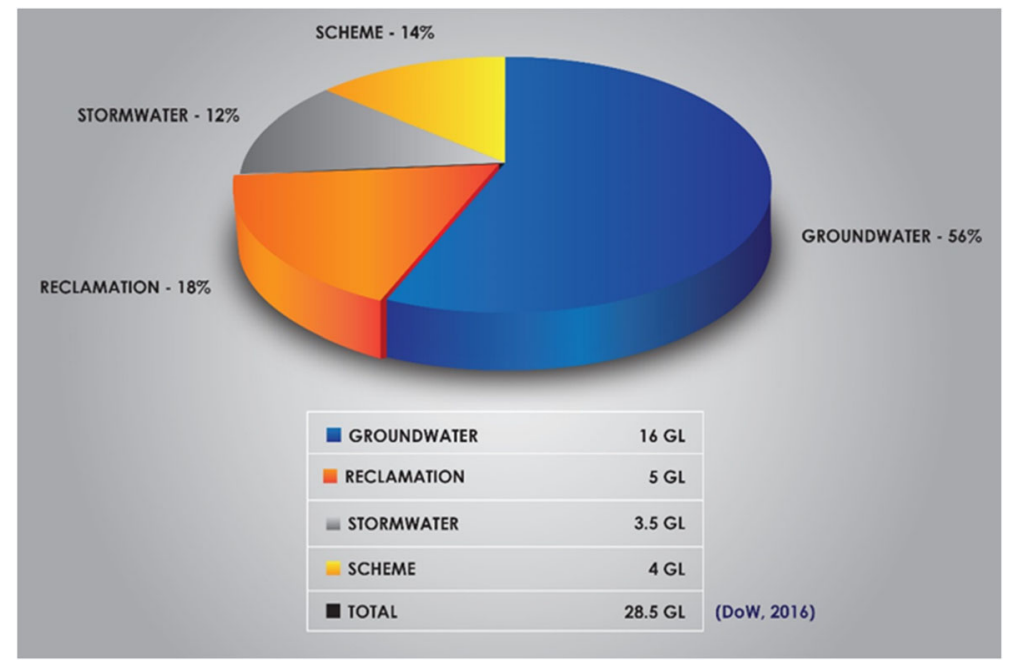

Fig. 6 KIA water sources and consumption (Source: (Meechan et al, 2019. Kwinana Industrial Area Water Management Strategy (unpublished report))) 
SDOOL $4.1 \mathrm{~km}$ off the WA coastline. The basic nature of the key water exchanges derived from the Figure 4 schematic are presented in Fig 7. Pricing and volumes are considered to be commercial in confidence and are not reported here.

Water use in the KIA is not an entirely closed water circuit because not all wastewater is reused. A proportion of actual wastewater is returned, under licence conditions, to the SDOOL and is lost to the system. Virgin process water entering the system comes from local aquifer groundwater or as potable water provided by Water Corporation. Input sources of re-used water come in the form of either refined (reverse osmosis) wastewater or as by-product exchanges including steam, de-mineralised or distilled water or wastewater that has been improved to a specified re-use standard as per the receiver's quality specifications. In Table 1, we identify the enterprises that produce water, whether potable or wastewater, as their core business, and in Fig. 8, their interconnectedness is laid out in a schematic diagram.

All of the enterprises in Table 1 are owned by Water Corporation, the State Government Trading Organisation (GTO) responsible for the production of potable water and for the management of wastewater. Some of these enterprises are contracted out to a third party to operate. The interrelationships are set out in Fig. 8. Two WWTPs, Woodman Point and East Rockingham, discharge their secondary-treated effluent out to the sea via the SDOOL. The Kwinana WWTP is the smallest of the three and has for over 40 years been infiltrating its secondary-treated effluent into the aquifer, with this water being generally recovered by a single nearby enterprise for industrial process use. The KWRP receives its input water from the SDOOL and operates continuously at its full production capacity. There are emerging plans to increase output capacity to partially meet increasing demand for process water from industry located nearby to the facility.

\section{Case Studies}

\section{Case Study 1: Managed Aquifer Recharge (MAR)}

The projected demand for industrial process water in the WTC could be as high as an additional 25GL by 2031 as per the published report. As the long-term solution to diminishing

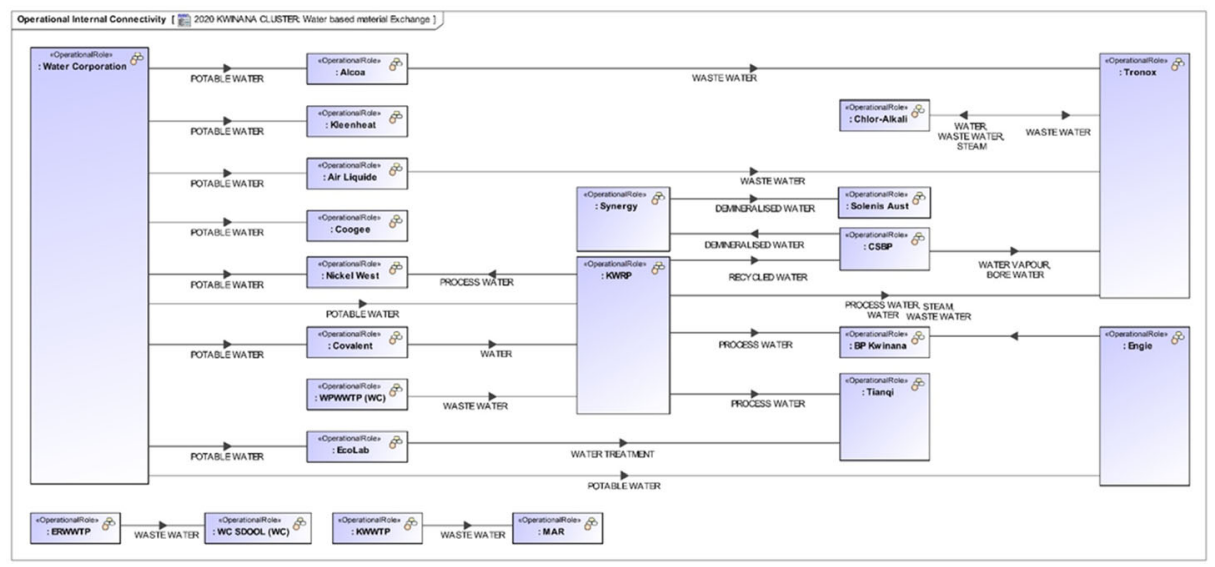

Fig. 7 Water-related product exchanges in Kwinana in 2020 (KISP (unpublished report) 2020) 
Table 1 Water utility infrastructure

\begin{tabular}{|c|c|c|c|}
\hline Enterprise & Product & Location & End use \\
\hline $\begin{array}{l}\text { Woodman Point } \\
\text { WWTP }\end{array}$ & Secondary-treated sewage & $\begin{array}{l}\text { Latitude } 32 \\
\text { industrial area }\end{array}$ & $\begin{array}{l}\text { Most pumped to ocean } \\
\text { via SDOOL } \\
\text { Source for KWRP }\end{array}$ \\
\hline Kwinana WWTP & Secondary-treated sewage & $\begin{array}{l}\text { Latitude } 32 \\
\quad \text { industrial area }\end{array}$ & Aquifer recharge \\
\hline $\begin{array}{l}\text { East Rockingham } \\
\text { WWTP }\end{array}$ & Secondary-treated sewage & $\begin{array}{l}\text { Rockingham } \\
\text { Industry Zone }\end{array}$ & $\begin{array}{l}\text { Pumped to the ocean via } \\
\text { SDOOL }\end{array}$ \\
\hline KWRP & $\begin{array}{l}\text { High-quality tertiary-treated }(\mathrm{RO}) \text { in- } \\
\text { dustrial process water }\end{array}$ & $\begin{array}{l}\text { Kwinana } \\
\text { Industrial Area }\end{array}$ & Industry process input \\
\hline $\begin{array}{l}\text { Perth Seawater } \\
\text { Desalination Plant }\end{array}$ & Potable water (RO) & $\begin{array}{l}\text { Kwinana } \\
\text { Industrial Area }\end{array}$ & $\begin{array}{l}\text { Scheme water for Perth } \\
\text { Some industry process } \\
\text { water }\end{array}$ \\
\hline
\end{tabular}

availability of inexpensive process water [45] (Meechan et al, 2019. Kwinana Industrial Area Water Management Strategy (unpublished report)), MAR is environmentally feasible [49, 50]. It is also technically and economically feasible [34, 44], and a multi-criteria analysis of three different process water supply strategy options was developed. In this analysis, "Strategy Two" schematically depicts MAR using SDOOL water as being the best of a range of the options to service the future needs of industry. This outcome is supported by industry in Kwinana (Fig. 9). Yet the project did not progress beyond phase one, the environmental analysis and the economic and design feasibility.

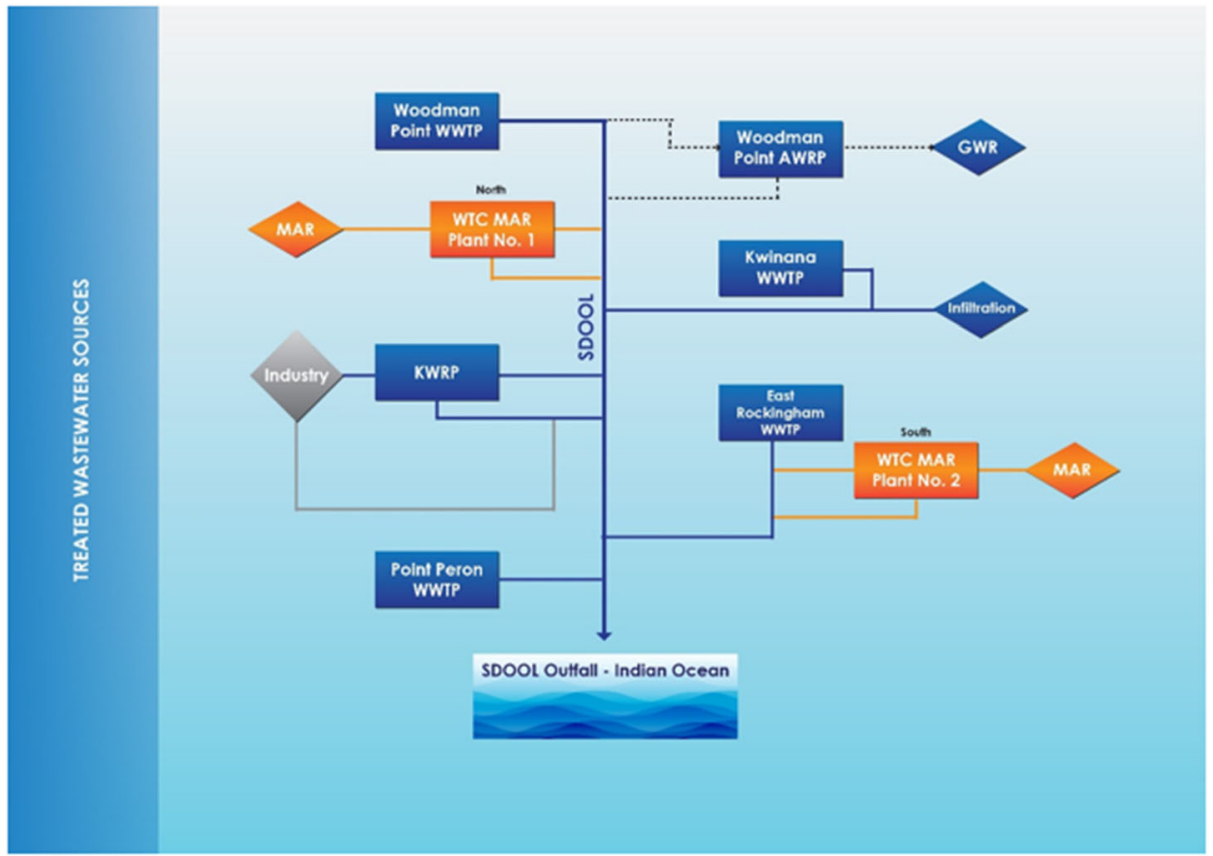

Fig. 8 SDOOL assets and connections (Source: (Meechan et al, 2019. Kwinana Industrial Area Water Management Strategy (unpublished report))) 
Why has the project not progressed to its phase two, which was construction and operation of two test sites? Analysing this using the KIC4 model reveals why.

\section{KIC4 Product, By-product and Utility Dimension-an Enterprise Interacting with other Enterprises within the Cluster}

Existing activity in this dimension demonstrated industry's willingness to participate in waterrelated exchanges, and expansion of these was strongly supported, including financially. There was significant precedent for water re-use initiatives. In Fig. 10, the 2020 exchange schematic was amended to reflect the known water-related exchanges between the enterprises located within the KIA. The schematic does not reflect the extensive re-use initiatives undertaken within a single enterprise, only those exchanges with other operating enterprises. This synergy dimension is clearly strong and mature. The failure of the MAR project lies elsewhere.

\section{KIC4 Skilled Workforce Dimension-the Collective Industries Interacting with the Cluster's Workforce}

There are already a large number of existing exchanges both between enterprises in Kwinana and within their own complex processes. There are a large number of water production and treatment facilities located within the WTC (refer to Table 1), and there are no evident constraints to the availability of a suitably skilled, qualified and experienced workforce to operate these facilities.

In addition, referring to Table 1 , the extent of water utility-related synergy exchanges indicates that within the participating enterprises, and usually within their environmental management sections, there is considerable expertise (and willingness) to find and explore exchange opportunities. Further water auditing [31,37] activity can be pursued internally

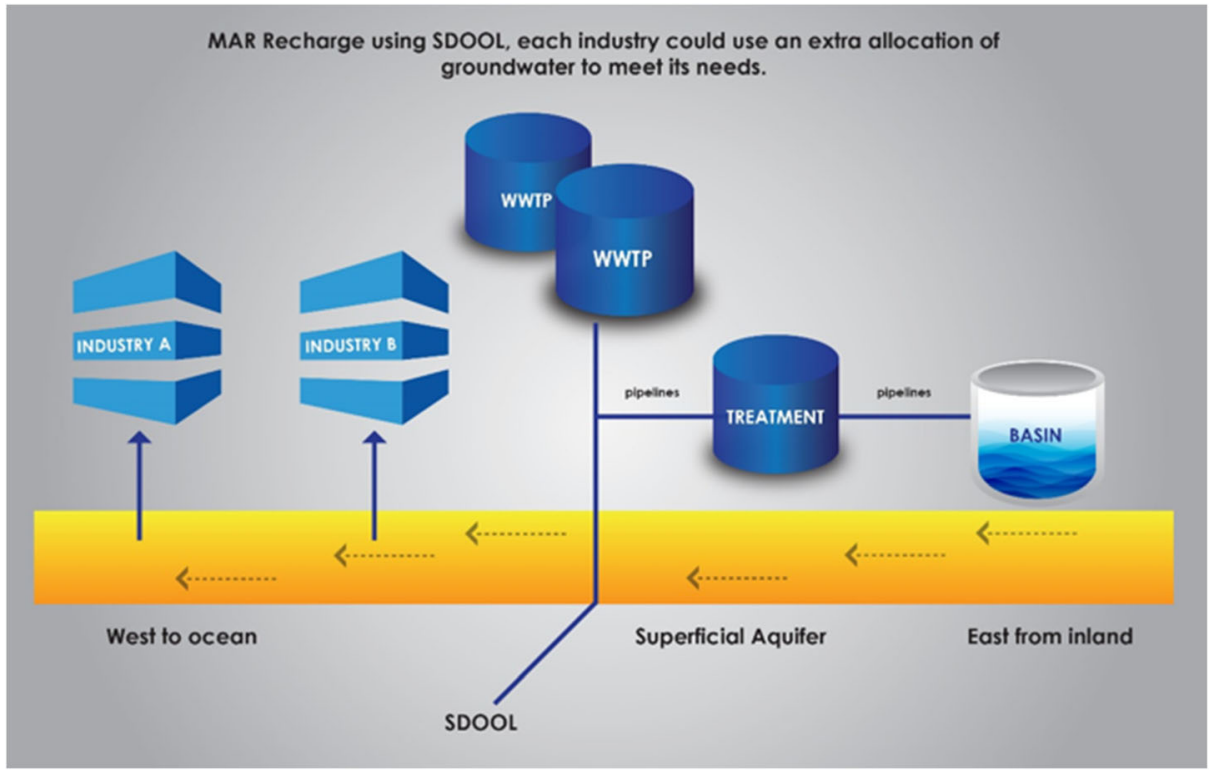

Fig. 9 MAR recharge using SDOOL (Source: [45]. (Meechan et al, 2019. Kwinana Industrial Area Water Management Strategy (unpublished report)) 


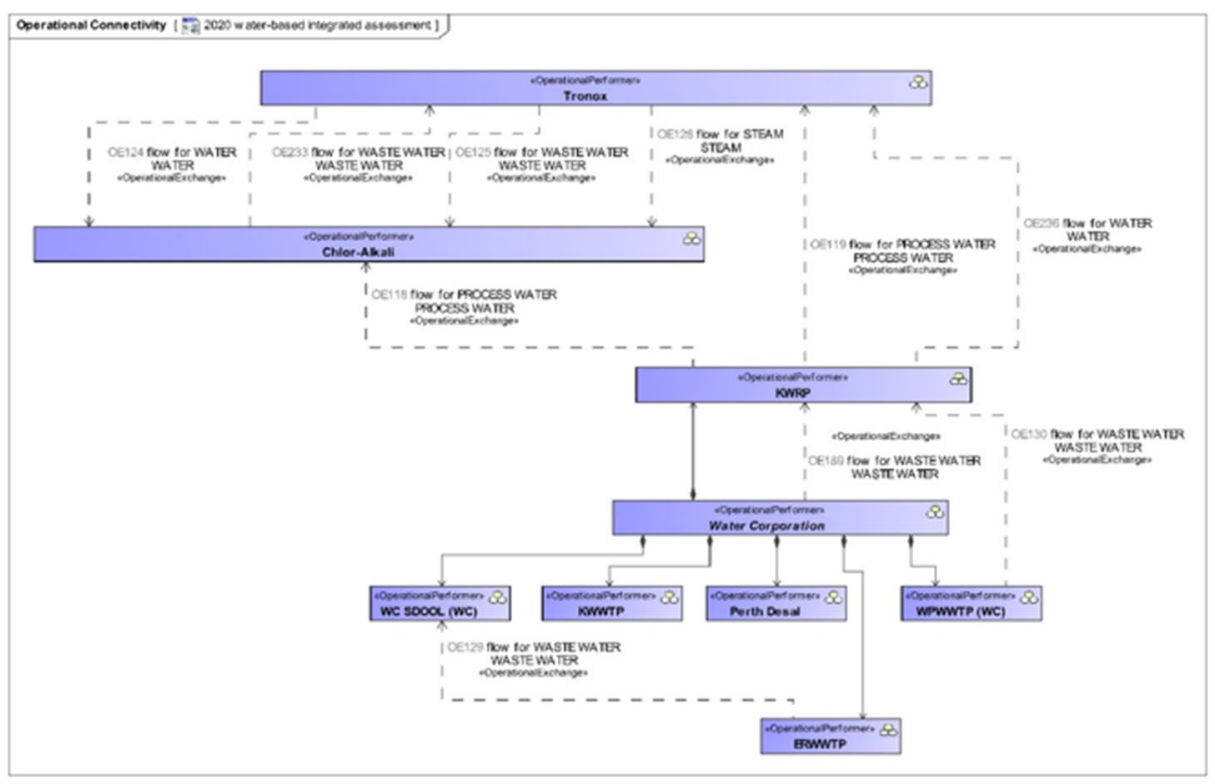

Fig. 10 Product/by-product supply relationships: Tronox-Chlor-Alkali and Water Corporation (KISP 2020)

within the enterprises to identify, quantify and evaluate these opportunities. This synergy dimension in relation to water is strong and mature. This synergy dimension is clearly strong and mature. The failure of the MAR project lies elsewhere.

\section{KIC4 Supporting Industry Dimension-the Collective Industries Interacting with the Support Industry Sector}

Local expertise in the construction and maintenance of MAR sites and associated infrastructure is available within the supporting industry sector. There are around 20 major companies located within the heavy industry core, yet there are 30 companies shown and several more that are not shown. The non-core companies, such as the KWRP and others, are considered to be operating within the support industry dimension, supplying materials (process water) to the heavy industries. Also included are the pipe manufacturers, technology designers, fabricators and installer companies. Their presence in or around the industrial complex means that the core industries can access the support industry materials and services, competitively. This interactivity is at the heart of the supporting industry synergy dimension, and it is working well. The presence of the support industries means that their prices will be competitive, unlike their prices in remote areas. In the remote areas where support industry services come with a premium, water synergy exchanges are more expensive and thus less likely to gain project approval. This synergy dimension in relation to water is strong and mature. The failure of the MAR project lies elsewhere.

\section{KIC4 Governance Dimension-the Interaction of Collective Industries with the Providers of Policy and Common Use Infrastructure}

The water regulator sets the regulatory standards for industry to achieve, they enforce the quality of water sought for re-use, and they tighten standards in response to community 
expectations. Individual companies have their own policy-driven (internal governance) water re-use targets. The existence of these policies drives investment in water-saving technologies. These are examples of the governance synergy dimension operating at multiple levels in both the private and public sectors to drive and to respond to change. The MAR solution was created as a project between government and industry to test whether or not MAR could resolve the process water restriction environment that was predicted to face industry in the coming years. The arrival of new entrant enterprises with a need for process water was predicted by industry to exacerbate the scarcity issue. KIC and the government agency responsible for the KIA, the (then) Department of State Development (DSD), provided joint seed funding to create a project whereby the environmental, physical, technical and environmental feasibility of a MAR project could be researched and pilot projects implemented. Members of the Project Steering Committee included KIC, DSD, the regulatory departments of Health and of Environment, Development WA (previously Landcorp - the industrial land manager) and CSIRO (the research partner). The Steering Committee worked together for over 2 years to progress the project through its initial environmental and technical feasibility stage and its subsequent stage being the economic feasibility assessment. The third and final stages were the actual construction of the two test sites identified in stage two.

Towards the very end of stage two, it was clear that:

- An application to the Environmental Protection Agency would be expected to receive an approval, given that MAR projects elsewhere had been previously approved.

- The localised MAR project utilising treated wastewater was technically and environmentally able to meet the required infiltration standards and could therefore be approved.

- The MAR water from the East Rockingham WWTP required no "polishing" before it was infiltrated; indeed, it was shown across some parameters to be of better quality than the groundwater it was being infiltrated into.

- Government policy on water recycling supported adding to industrial process water supply through the re-use of wastewater.

- The regulatory departments (Health and Water) had raised no issues of concern that were not satisfactorily addressed throughout the course of the project meetings.

- Two infiltration gallery sites were identified, with the ultimate siting decision being made with the awareness of downstream implications on legacy plumes in the groundwater under the industrial area.

The project failed at the end of stage two, at the last meeting of the Steering Committee. The water regulator advised it had identified a new concern, this being that infiltrated MAR water could intersect with some legacy plumes and that there may be an unknown chemical reaction as a result, and so, industry was advised that it would be required to accept the risk associated with this and to undertake to remedy any issues that might arise. Acceptance of the new risk was a requirement to progress to the next stage of the project. Quantification of this sort of a risk is extremely difficult, and so, industry's response was that the risk was unacceptable, and the project stopped at that point. The decision was made not to proceed with implementation of the trial sites. Hundreds of thousands of dollars were effectively wasted. The positive outcome was, however, that high-quality scientific and economic research was completed, and it is clear that MAR is entirely feasible in Kwinana. The interaction of collective industries with the public sector suddenly became dysfunctional, and what was otherwise a viable and necessary project for the future sustainability of the KIA and its industries was stopped in its tracks. The 
overall competitiveness of the industrial area has thus had a setback, and its attractiveness to potential new entrants is diminished. This is a good example where a failure in the governance dimension was responsible for the termination of the project. The failure of the MAR project lies in the governance dimension.

\section{Case Study 2: Successful Delivery of Water Treatment Materials during COVID-19}

Perth's drinking water supply chain includes the acquisition of sodium hypochlorite for scheme water sterilisation purposes. That product is manufactured in Kwinana by Chloralkali (a subsidiary of Coogee Pty Ltd), and the Water Corporation is one of their customers. Whilst the Water Corporation has contingency plans for alternative supply sources for this essential product, analysis of the overall supply chain under the KIC4 model remains a useful example of what happens when all four dimensions are present and providing a conducive environment for industrial connectivity. Analysing this using the KIC4 model reveals why. During the early months of the COVID-19 outbreak, the state's Premier quickly formed his "Premier's Pandemic Coordination Committee", which was populated with a range of public servants. The WA government was implementing rapidly made decisions, including the introduction of regional borders within the state and interstate with Australia's other states and territories.

The Chlor-alkali plant is located in the KIA and relies on the supply of steam from its neighbour, Tronox. Tronox manufactures titanium dioxide (a common pigment) for export to the world. A by-product of that process is steam, and this is supplied to the Chlor-alkali plant as an input into its manufacturing process. For Tronox to continue to operate, it needs a steady supply of its raw material, rutile, from a mine site in a region to the north of Perth. With the state-imposed closing down of travel between the regions, it was considered a possibility that the Pandemic Coordinating Committee would stop the flow of raw materials, such as rutile, to industry. KIC made representations on behalf of its members to the Committee, and as a result of this, there was no collateral knock-on effect that could have resulted in the interruption of essential supplies. Had this approach been ineffective, the manufacture of Chlor-alkali's hypochlorite would have ceased. But for the existence of supply contingency plans, and it was uncertain that these would be available, the manufacture of Perth's water supply could have been placed in danger, as would a number of local manufacturing enterprises that rely on Chlor-alkali's product. These exchanges are depicted in Fig. 10.

KIC1 Product, By-Product, and Utility Dimension-an Enterprise Interacting with Other Enterprises within the Cluster

The supply of steam is the uniting synergy exchange between the two enterprises, being Coogee and Tronox. It represents the classic by-product water synergy exchange. This synergy dimension in relation to water is strong and mature.

\section{KIC2 Skilled Workforce Dimension-the Collective Industries Interacting with the Cluster's Workforce}

There are already a large number of existing exchanges both between enterprises in Kwinana, and within these enterprises, there is clearly no issue with a lack of skills and qualified expertise, including the movement of bulk dangerous goods from suppliers to receivers 
operating within complex industrial chemical processing plants. This synergy dimension in relation to water is strong and mature.

\section{KIC3 Support Industry Dimension-the Collective Industries Interacting with the Support Industry Sector}

Support industries interacting with this exchange are the mining and transport contractors servicing both Tronox (rutile supply, transporting loaded shipping containers of containerised product to the port) and Chlor-alkali, moving hypochlorite to the Water Corporation. These support industries needed to be in close contact with their customers because it would be easy for the supply chains to fail when faced with the unprecedented supply chain complexities that COVID-19 presented. This synergy dimension in relation to water is strong and mature.

\section{KIC4 Governance Dimension-the Interaction of Collective Industries with the Public Sector}

The public sector populated the Pandemic Coordinating Committee. It was clear the members were scrambling to come to terms with understanding the task ahead and then responding to it in a way that kept the essential industries operating. Initial conversations indicated that there was little comprehension within the Committee that the interconnectedness of enterprises in Kwinana (the first-dimension exchanges) could fail if an individual operator was removed (shut down) from its connecting enterprises. Because of the reputation of KIC, communication around this aspect was openly received and consequently effectively managed. The realisation of the interconnectedness assisted in some way to the broadening of the term "essential industries", and thus, relaxed borders for the necessary supply chain transport were secured. The availability of Perth's potable water supply and the supply of process water to potablereliant water supplies was assured. This assurance meant that other enterprises within the Kwinana cluster, relying on potable water supplies or hypochlorite for their production processes, could continue to operate. This scenario portrays a highly effective governance synergy dimension in relation to water, where industry collectively relied on the public service to understand its needs and the public service relied on the information provided to them.

\section{Conclusions}

The KIA is one of the leading examples in the world of IS. Researchers around the world have focused their attention primarily on the nature of materials exchanged, increasing the opportunities and drivers for exchanges to occur and exploring the broader economic, environmental and social benefits that accrue when material exchange is operating strongly. The literature reveals an evolutionary change in the thinking over the past 40 years, advancing IS from being focused on product and by-product exchanges, through to more expanded perspectives including industry culture, knowledgeable workers and support industry participation. This paper has demonstrated a continuation of this evolution of thought by testing a new fourdimensional KIC4 model for IS through a focus on the KIA industrial cluster. There is an extensive array of reasons why an industrial area does not thrive or where product, by-product or utility synergy do or do not establish. We considered some reasons for this in the context of the water circular economy in Kwinana through reference to the KIC4 model for IS. Its multi- 
dimensional perspective builds on the traditional and limited conceptualisation of IS. Four dimensions of IS were developed:

1. The traditional product and by-product dimension, where, simplistically, the output material of one enterprise becomes the input of another

2. The skilled workforce synergy dimension where the skilled and experienced workforce associated with the entire industrial cluster expresses fluidity between employers

3. The support industry synergy dimension, where these enterprises are located nearby to the industrial cluster so that their products and services are easily accessed and tailored to client's needs

4. The governance dimension where policy, regulation, statutes and strategic industrial planning come together to facilitate the international competitiveness of the enterprises within the cluster.

The two brief circular water economy case examples were presented to demonstrate the application of the theory behind the model. The first demonstrated a failure in the governance dimension which stopped a major MAR project, thus denying the opportunity to resolve a well-documented shortage of industrial process water. The second succeeded because of the obvious strength of the product exchanges in the first dimension which demonstrated the interconnectedness of the cluster and the willingness of those people operating within the governance dimension to trust this strength. Just as a dimension one exchange, between a sending enterprise and a receiving enterprise, can improve competitiveness, so too can the conducive environment of a collective skilled workforce (second dimension) improve the competitive strength of individual enterprises located within the cluster. In the same way as this, the presence of the support industry sector (third dimension) and the exchanges of goods and services improves the output capacity of the cluster's enterprises. Fourth-dimensional exchanges refer to the relationship between those with a governance influence across the cluster and thus an influence on each enterprise's individual competitive position.

An industrial environment which exhibits a good balance of all four dimensions creates the opportunity for incoming enterprises to "plug in" to these synergistic exchanges. Doing so creates the opportunity to minimise their ongoing operating costs through the ease with which they can enter the existing product/by-product exchange synergy flows, employ a local and skilled workforce, engage with local support industry capabilities and take advantage of an established regulatory, policy and common user infrastructure environment. It presents the new entrant with an opportunity to positively affect the enterprise competitiveness, and this is good for the shareholders and for the environment. It's also good for cluster enterprises that are connected with each other through the various dimensional exchanges. The bigger and more diverse the industrial base in the industrial cluster, the more robust is the local workforce skill set and availability, the stronger is its support industry presence and the more will new industry be facilitated through the complexities of the planning and regulatory processes. In the case studies, it is demonstrated that if one or more of the dimensions is deficient or is dysfunctional, the opportunity for a well-functioning circular economy is diminished.

We conclude that of itself, the traditional view of IS is not a system, but an individual dimension of a system: a sub-system, which is only one of a number of interconnected systems. The current literature we reviewed did not seem to contemplate this view. We posit that IS does appear to be comprised of the four dimensions put forward as the KIC4 model. We conclude that achieving a circular economy in a complex industrial cluster, such as Kwinana, 
is made a great deal easier when the four synergy dimensions are strong, visible, supportive and energetically embraced by all.

Acknowledgements The assistance of Engineering undergraduate and postgraduate students at Murdoch University, Ella Meechan, Ronald Ncube and Ivan Quintero, for their data collection towards their unpublished study entitled "Kwinana Industrial Area Water Management Strategy" is gratefully acknowledged. Also, we thank master's students Lhachey Ugyen, Shefali, Miriam Laizer, Austin Macwan and Hitesh Bhati for their data collection towards their unpublished internship report to KIC entitled "Kwinana Industrial Symbiosis Project (KISP) 2020".

Availability of Data and Material Availability is assured by contacting the corresponding author.

Code Availability Not applicable.

\section{Declarations}

Competing Interests Mr. Oughton (lead author) is employed as the Director of Kwinana Industries Council.

\section{References}

1. Chertow MR (2000) Industrial symbiosis: literature and taxonomy. Annu Rev Energy Environ 25:31233337

2. Chertow MR (2001) The IPAT equation and its variants; changing views of technology and environmental impact. J Ind Ecol 4(4):13-29

3. Kurup BR (2007) Methodology for capturing environmental social and economic implications of industrial symbiosis in heavy industrial areas, in Division of Science \& Engineering. Dessertation, Curtin University: Perth, Australia. https://espace.curtin.edu.au/bitstream/handle/20.500.11937/1775/128365 Kurup2007.pdf

4. Ayres R (1989) Industrial metabolism. In: Ausubel JH, Sladovich H (eds) Technology and the Environment. Acad Press, pp 23-49

5. United Nations Sustainable Development (1992) Agenda 21, United Nations Conference on Environment \& Development, United Nations Conference on Environment \& Development: Brazil. p. 1-351

6. Wallner HP, Narodoslawsky M, Moser F (1996) Islands of sustainability: a bottom-up approach towards sustainable development. Environ Plan 28:1763-1778

7. Wallner H, Narodoslawsky M (1996) Evolution of regional socio-economic systems toward "islands of sustainability.”. J Environ Syst 24(3):221-240

8. Lifset R (1997) A metaphor, a field, and a journal. J Ind Ecol 1(1):1-3

9. Neves A et al (2020) A comprehensive view of industrial symbiosis. J Clean Prod 247(20)

10. Frosch RA, Gallopoulos NE (1989) Strategies for manufacturing. Sci Am 261:144-152

11. Harris S (2008) ARC report: bulletin no 3: mechanisms to enable regional resource synergies, Curtin University of Technology: Perth, Australia

12. van Beers D (2006), Capturing regional synergies in the Kwinana industrial area - 2006 status report., Curtin University. https://www.researchgate.net/publication/242490431_Capturing_Regional_Synergies_in_the_ Kwinana Industrial Area

13. Bossilkov A, van Beers D, van Berkel R (2005), Industrial symbiosis as an integrative business practice in the Kwinana industrial area: lessons learnt and way forward, in 11th International Sustainable Development Research Conference at: Helsinki, Finland. https:/espace.library.uq.edu.au/data/UQ_346084/UQ346084_ report.pdf

14. van Beers D, et al. (2008) Industrial symbiosis in Australian mineral industry: the cases of Kwinana and Gladstone. J Ind Ecol

15. van Beers D, Biswas WK (2008) A regional synergy approach to energy recovery: the case of the Kwinana industrial area. Western Australia Energy Conversion and Management 49:3051-3062

16. van Berkel R (2007) "Industrial symbiosis: regional sustainable development through innovation across business boundaries.". J Ind Ecol

17. Kurup B, Stehlik D (2009) Towards a model to assess the sustainability implications of industrial symbiosis in eco-industrial parks. Progress in Industrial Ecology-An International Journal 6(2):103-119 
18. Lombardi DR, Laybourn P (2012) Redefining industrial symbiosis: crossing academic-practitioner boundaries. J Ind Ecol 16:28-37

19. Jensen PD, Basson L, Hellawell EE, Bailey MR, Leach M (2011) Quantifying 'geographic proximity': experiences from the United Kingdom's national industrial symbiosis programme. J of Resources, Conservation \& Recycling 55:703-771

20. Jensen $\mathrm{P}$ et al (2011) The role of geospatial industrial diversity in the facilitation of regional industrial symbiosis. In: Centre for Environmental Strategy, Guildford

21. Luciano A, Barberio G, Mancuso E, Sbaffoni S, la Monica M, Scagliarino C, Cutaia L (2016) Potential improvement of methodology for industrial symbiosis implementation at regional scale. Waste and Biomass Valor 7:1007-1015

22. Golev A, Corder GD, Giurco DP (2014) Barriers to industrial symbiosis: insights from the use of a maturity grid. J Ind Ecol 19(1):141-153

23. Moreau V et al (2017) Coming full circle: why social and institutional dimensions matter for the circular economy. J Ind Ecol 21(3)

24. United Nations (2015) Transforming our world: the 2030 agenda for sustainable development. https://www. un.org/ga/search/view doc.asp?symbol=A/RES/70/1\&La

25. Cecchin A, et al. (2020) Relating industrial symbiosis and circular economy to the sustainable development debate, in Industrial Symbiosis for the Circular Economy: Operational Experiences, Best Practices and Obstacles to a Collaborative Business Approach, Roberta Salomone, et al., Editors. Springer International Publishing: Switzerland. https://doi.org/10.1007/978-3-030-36660-5_1

26. Álvarez R (2017) and Ruiz-Puente. C, Development of the tool SymbioSyS to support the transition towards a circular economy based on industrial symbiosis strategies. Waste Biomass Valor 8(8):15211530. https://doi.org/10.1007/s12649-016-9748-1

27. Domenech T, Davies M (2011) The role of embeddedness in industrial symbiosis networks: phases in the evolution of industrial symbiosis networks. Bus Strateg Environ 20:281-296

28. Tseng ML, et al (2020) Circular economy enables sustainable consumption and production in multi-level supply chain system,. J of Resources Conservation and Recycling, 154

29. SKM \& REU (2014) Western-trade-coast integrated assessment: environmental, social and economic impact. https://kic.org.au/wp-content/uploads/2020/02/Western-Trade-Coast-Integrated-AssessmentEnvironmental-Social-and-Economic-Impact_RS_September-2014.pdf

30. Harris S, van Berkel R, and Kurup B (2008) Fostering industrial symbiosis for regional sustainable development outcomes; : in CRRC 2008. Queen's University, Belfast

31. Barrington D, Ho G (2014) Towards zero liquid discharge: the use of water auditing to identify water conservation measures. J Clean Prod 66:571-576

32. Department of Water (2003) State Water Strategy. Government of Western Australia, Perth

33. Department of Water (2008) State Water Recycling Strategy, Perth: Government of Western Australia. https://www.water.wa.gov.au/_ data/assets/pdf_file/0016/1627/80011.pdf

34. Greenwood J, et al. (2016) Nitrogen budget for Cockburn Sound, Western Australia, Perth, Western Australia: Report to the Cockburn Sound Management Council and the Western Australian Department of Water. CSIRO: Perth. https://www.water.wa.gov.au/_data/assets/pdf_file/0019/1765/106021.pdf

35. Water Corporation (2020) Sepia depression ocean outfall landline annual summary report (SDOOL). https:// pw-cdn.watercorporation.com.au/-/media/WaterCorp/Documents/Our-Water/Wastewater/Ocean-outfall/ Perth-monitoring-program/sdool-annual-report-2020.pdf

36. GHD (2018) Western trade coast managed aquifer recharge scheme engineering design and costing study. 2018, DJTSI.: Perth. https://kic.org.au/wp-content/uploads/2020/02/Report-to-NWIDF\%E2\%80\%93WTCMAR-of-Treated-Wastewater-for-Industrial-Water-Supply_RS_April-2019.pdf

37. Barrington DJ, Prior A, Ho G (2013) The role of water auditing in achieving water conservation in the process industry. J Clean Prod 52(1):356-361

38. Department of Water (2016) Western Trade Coast heavy industry local water supply strategy, Securing Western Australia's water future,. Department of Water: Perth. https://www.water.wa.gov.au/_ data/assets/ pdf_file/0019/1765/106021.pdf

39. NRMMC, E., NHMRC (2009) Australian guidelines for water recycling: managing health and environmental risks (phase 2) - managed aquifer recharge,. Natural Resource Management Ministerial Council, Environment Protection and Heritage Council, National Health and Medical Research Council. : Canberra. https://www.nhmrc.gov.au/about-us/publications/australian-guidelines-water-recycling

40. NRMMC, E., NHMRC (2006) Australian guidelines for water recycling: managing health and environmental risks (phase 1), National Resource Management Ministerial Council, Environmental Protection and Heritage Council, National Health and Medical Research Council. : Canberra

41. Department of Health (2015) Guidelines for the non-potable uses of recycled water in Western Australia, Perth: Department of Health,. Department of Health. : Perth. https://ww2.health.wa.gov.au/-/media/Files/ 
Corporate/general-documents/water/Recycling/Guidelines-for-the-Non-potable-Uses-of-Recycled-Waterin-WA.pdf

42. Department of Water (2011) Operational policy 1.01 - managed aquifer recharge in Western Australia, Department of Water.: Perth Australia. https://www.wa.gov.au/sites/default/files/2021-01/Policy_ Managed_aquifer_recharge_in_Western_Australia.pdf

43. GHD (2017) WTC $\bar{C}$ MAR Scheme - Engineering design \& costing study: report on assessment of selected MAR sites (WP1). Department of State Development (now Department of Jobs, Tourism, Science and Innovation): Perth. https://kic.org.au/wp-content/uploads/2020/02/Report-to-NWIDF\%E2\%80\%93WTCMAR-of-Treated-Wastewater-for-Industrial-Water-Supply_RS_April-2019.pdf

44. GHD (2019) National water infrastructure development fund Western Trade Coast managed aquifer recharge of treated wastewater for industrial water supply feasibility study, Department of JTSI. https:// kic.org.au/wp-content/uploads/2020/02/Report-to-NWIDF\%E2\%80\%93WTC-MAR-of-TreatedWastewater-for-Industrial-Water-Supply_RS_April-2019.pdf

45. Synergies (2018) Commercial feasibility assessment: managed aquifer recharge of treated wastewater for industrial supply in the Western Trade Coast, . 2018, DJTSI: Perth

46. Castilla JC, Donn MJ, Charles SP (2018) Western Trade Coast hydrological model - conceptual model report. Western Trade Coast managed aquifer recharge of treated wastewater for industrial water supply Feasibility study. Milestone update to National Water Infrastructure Development Fund., CSIRO: Perth, Australia. https://kic.org.au/wp-content/uploads/2020/02/Report-to-NWIDF\%E2\%80\%93WTC-MAR-ofTreated-Wastewater-for-Industrial-Water-Supply_RS_April-2019.pdf

47. M. J., V. and T. J. L. \& Cui (2019) Western Trade Coast managed aquifer recharge - risk assessment,. CSIRO: Perth

48. Cui TDMJ (2019) Calibration and scenario modelling of the WTC groundwater model. Western Trade Coast managed aquifer recharge of treated wastewater for industrial water supply - Feasibility study, CSIRO: Australia. https://publications.csiro.au/rpr/pub?pid=csiro:EP189106

49. Donn MJ, Page DW, Vanderzalm JL (2017) Treated wastewater disposal via infiltration environmental research project: final report (Commercial-in-confidence). 2017, CSIRO: Australia

50. Harris S (2007) Industrial symbiosis in the Kwinana industrial area (Western Australia). Measurement and Control 40:239-244 